\title{
US science's 'stealth agency'
}

\section{Washington}

A SHADOWY White House office working under Vice President Dan Quayle is emerging as one of the biggest behind-the-scenes players in Washington science politics. Not surprisingly, that is starting to make a lot of people nervous.

The President's Council on Competitiveness is the successor to the Reagan-era Task Force on Regulatory Relief - and to the Task Force's controversial deregulation policies. Almost every government policy and decision is eligible to be sent through the Council for approval, if the White House sees fit.

The Council looks for policies in fields such as the environment, drug approval, risk assessment and laboratory regulation that may damage the country's economic health. Potentially, this could include nearly everything. In practice, the Council has chosen to make research fields one of its highest priorities, arguing that over-regulation and an excessive focus on government support in science and technology is particularly damaging to competitiveness.

For instance, at a meeting last week of the President's Council of Advisors on Science and Technology (PCAST), Allan Hubbard, executive director of the Council, said his staff is exploring ways to improve technology transfer at the national laboratories of the Department of Energy and the National Institutes of Health. "We're thinking that perhaps we should take away a little R\&D money and require the labs to find private co-investors" to make up the difference, he said.

PCAST member John Foster, a former director of the Lawrence Livermore $\mathrm{Na}$ tional Laboratory, thought it was a great idea. "We're spending too much on the labs," he agreed. "Let's cut their spending by 10 to 15 per cent to get their attention. Then take half of that and offer it back to them as long as they can find matching funds from industry." Hubbard promised to offer Foster's proposal to a Council working group on the issue.

Whether or not such a cut actually shows up in the national laboratory budgets, the episode illustrates the power the Council can wield.

Last year, after long negotiations with industry and activist groups, Congress passed a bill to make it more difficult for a drug to qualify as an 'orphan', one whose target audience is too small to justify research and development cost without special market protections. But on 9 November, President Bush vetoed the bill, catching almost everyone off guard. Who was behind the reversal? A fact sheet explaining the veto told the whole story with its letterhead alone - it came from the Council on Competitiveness.

Critics charge that the Council is essen- tially a law unto itself. Operating in secrecy, free from Freedom of Information Act requests and answerable only to the President, the Council is a 'stealth agency', they claim. This month, for instance, the non-profit investigative group OMB Watch offered a dozen cases of Council 'interference' in environmental and health regulations, from reduction of wetlands standards to delays in quality-control reforms at clinical laboratories. "The Council has turned the term 'competitiveness' into a buzzword for eliminating regulations that corporations oppose," says OMB Watch executive director Gary Bass.

Industry takes a different view. Biotechnology companies showered the Council with praise in February, when it released a report calling for a reduction in the 'burden of regulation' on the industry.

Hubbard defends the Council as the last bastion of good sense in a bureaucracy that would regulate the country to an economic standstill, given the chance. "The role of the Council is to see that government is not interfering any more than is necessary in business," he told PCAST. "I don't see why cost-benefit analysis shouldn't enter into every regulation."

In the upcoming months, the Council will have even more opportunities to flex its muscle on:
Food and Drug Administration (FDA) drug approval. A council task force chaired by Former Health and Human Services deputy director Constance Horner is about to recommend major FDA reforms. One option that has been considered is privatizing the drug-approval arm of the agency by running it as a business based on user fees, much like the UK Medicine Control Agency. Other ways to streamline drug approval include 'fast tracking' more cancer and AIDS drugs, harmonizing US standards with those in other countries, including accepting data from foreign trials, and increasing the use of outside advisory bodies like the institutional review boards at many hospitals and universities.

Biotechnology. A Council working group is preparing to release a final version of its 'SCOPE' plan for biotechnology regulation. The new plan is expected to change existing regulation by setting levels of regulatory oversight based on the real risk inherent in the product rather than the process used to make it, an approach known as 'performance based' regulating.

Clean Air Act. The Council has been given the lead in turning last year's Clean Air Act into actual regulations. Hubbard says that the principal aim will be to reduce the measure's estimated $\$ 25,000$ million cost to US industry.

Christopher Anderson

\section{A new role for DARPA?}

\section{Washington}

SINCE the end of the Second World War, the US Department of Defense has been by far the leading supporter of research and development (R\&D) in the United States, and even with the collapse of the Communist Bloc, that is unlikely to change soon. Nonetheless, as economic competitiveness becomes a more important part of national security and military superiority becomes less urgent, the US government may start to look to defence R\&D for more than high-technology weaponry.

That, at least, is the suggestion of a report released last week by the Carnegie Commission on Science, Technology and Government, a private group comprising distinguished scientists, community leaders and former government officials. The report, which was the subject of a hearing by the congressional Joint Economic Committee, contains a variety of prescriptions for helping US economic performance, but the most controversial centres on the interplay between military and commercial R\&D.

"The United States now has two technology bases, a defence technology base and a commercial technology base," said retired Admiral Bobby Inman, chairman of the group that prepared the report. "The nation must move toward a single national technology base." To that end, the report says, the Defense Advanced Research Projects Agency (DARPA), which funds research into advanced technology with potential military applications, should be transformed into the National Advanced Research Projects Agency (NARPA). NARPA not only would fund military research but also would support research into advanced civilian technologies that federal agencies other than the defence department request.

DARPA, Inman noted, has a good record in funding 'dual use' technologies - those with both a military purpose and potential commercial applications. Reconstituted as NARPA, it could be expected to play a big role in promoting research with long-term commercial rewards.

The suggestion for a NARPA-toDARPA transformation, however, has much more to do with assuring that the defence department has access to the best technology than in improving economic competitiveness, said Lewis Branscomb of Harvard University, a member of the group that prepared the report. When the military employs dual-use technology, it 